\title{
Kajian Transformasi Visual Desain Karakter Eevee pada Game Pokémon Series Generasi I-V
}

\author{
Dewi Isma Aryani, Imam Santosa \& Alvanov Zpalanzani \\ Fakultas Seni Rupa dan Desain, Program Studi Magister Desain, \\ Institut Teknologi Bandung, Jalan Ganesa No. 10 Bandung 40132, Indonesia \\ Email: dewi_isma_aryani@yahoo.com
}

\begin{abstract}
Abstrak. Game Pokémon series merupakan salah satu wujud representasi dari kebudayaan media yang menyajikan sebuah dunia simulasi dengan membangun tanda-tanda di dalamnya melalui storyline, gameplay, environment, maupun karakter-karakter game, sehingga menjadi sebuah budaya digital. Desain karakter Pokémon, dalam hal ini adalah Eevee, mampu menimbulkan faktor penasaran dan kecanduan pada penggemarnya akibat penerapan metode mangamatrix, teori warna, dan teknik morphological forced connections melalui transformasi visual desain karakternya. Penelitian ini merupakan penelitian kualitatif berdasarkan penerapan prinsip manga-matrix meliputi faktor internal dan eksternal pada karakter, analisis persamaan atau relasi antar teori yang berkaitan dengan unsur visual dan interpretasi makna karakter, serta perpaduan teori-teori pada desain karakter sebagai cerminan ideologi atau pola pikir Satoshi Tajiri dalam hal implementasi kebudayaan Jepang. Hasil identifikasi analisis data transformasi visual desain karakter Eevee memiliki benang merah persamaan dengan keberadaan elemen-elemen tambahan pada keragaman bentuk visualisasi karakter Eevee. Ragam bentuk Eevee tersebut menjadi dasar pemikiran dan penciptaan karakter sebagai media pengenalan transformasi visual desain karakter suatu game, dalam hal ini adalah game Pokémon series.
\end{abstract}

Kata kunci: game; karakter; Manga-matrix; Pokémon; transformasi visual desain.

Abstract. Pokémon game series is a representation of the media culture that offers a world of simulation by creating signs through storyline, gameplay, environment, as well as game characters, so that it becomes a part of digital culture. The design of Pokémon character, in this case is Eevee, is able to generate its fans curiosity and addiction resulted from the application of Mangamatrix method, color theory and morphological-forced-connections technique through the visual transformation of character design itself. This study is a qualitative research that conducted through the application of Manga-matrix principle including internal and external factors on the characters, similarity analysis or the relation among the theories connected to visual element and the interpretation of character meaning, and the combination of character design theories as the reflection of the Satoshi Tajiri as well as Japanese society's ideology or thinking pattern in cultural implementation. The analysis shows that Eevee's changing form still contains similarity with its existence of additional elements creates variety of forms in Eevee's character visualization. Those

Received September $3^{\text {rd }} 2012$, Revised September $9^{\text {th }}, 2013$, Accepted November $29^{\text {th }}, 2013$.

Copyright (C) 2013 Published by LPPM ITB, ISSN: 1978-3078, DOI: 10.5614/itbj.vad.2013.5.2.5 
Eevee's form variety becomes the essence of the creation of the character as the media that introduces the visual transformation of character design in a game, in this matter is the Pokémon game series.

Keywords: character; design visual transformation; game; Manga-matrix; Pokémon.

\section{$1 \quad$ Pendahuluan}

Salah satu genre game yakni role-playing game (RPG) merupakan permainan dengan tingkat kompleksitas yang cukup tinggi. RPG bukan hanya permainan yang hanya bertujuan untuk menyelesaikan misi, melainkan lebih ditekankan pada kemampuan pengembangan atau building system. Perbedaan tingkatan (level) yang ada dalam game merupakan media pembeda antara karakter satu dengan yang lain meliputi: kekuatan, tampilan visual, sifat, dan sebagainya. Perbedaan tersebut tidak hanya terbatas pada karakter saja, melainkan juga perbedaan pengembangan skill dan item dalam sebuah permainan.

Pokémon merupakan salah satu contoh permainan digital yang menggunakan peran multimedia dalam penyebarannya, dengan menciptakan faktor keingintahuan (curiousity) penggemarnya melalui karakter-karakter Pokémon yang mampu bertransformasi, berubah menjadi karakter lain dengan kemampuan yang berbeda. Menurut Smardon [1], pengertian karakter secara umum adalah salah satu atribut atau ciri-ciri yang membuat objek dapat dibedakan sebagai sesuatu yang sifatnya sangat individual. Dengan demikian, karakter yang dimaksud lebih kepada penekanan karakter melalui ciri-ciri visual atau ciri-ciri yang dapat dicerna dengan indera visual/mata seorang pengamat. Kemampuan visual seorang pengamat dalam proses mencerna suatu objek fisik untuk mudah dikenali diakibatkan oleh pola yang dapat dibaca dan mampu menimbulkan image, yang dibentuk oleh keterkaitan atau hubungan timbal balik di antara pola-pola elemen dasar melalui dominasi, keragaman, kontinuitas, dan lain-lain.

Game Pokémon series hingga saat ini telah memasuki generasi $\mathrm{V}$ dengan menampilkan 649 karakter Pokémon, yang terdiri dari beberapa jenis/tipe dengan kelemahan dan keunggulan tersendiri terhadap tipe-tipe tertentu. Seperti Pokémon air yang unggul melawan Pokémon tipe tanah, namun lemah terhadap Pokémon tipe listrik. Tidak dapat dipungkiri bahwa karakter-karakter monster dalam game Pokémon series, sejak generasi I hingga generasi terakhir (V), memiliki keanekaragaman visual maupun nature yang melekat pada setiap karakter. Sebagaimana pemaparan Fox [2] tentang elemen-elemen interaktif sebagai pembangun user experience dalam suatu game, yakni: warna, sistem navigasi, lay-out interface, text-picture, karakter, dan konten visual, yang akan dijadikan sebagai landasan dalam proses analisis mengenai visualisasi karakter Eevee dalam game Pokémon series. Eevee dikenal sebagai Pokémon Evolusi 
yang memiliki kode genetis tidak stabil, sehingga memungkinkan Eevee untuk berubah bentuk (transformasi) menjadi bentuk lain sesuai dengan situasi tertentu. Hingga saat ini, generasi V game Pokémon series, Eevee memiliki tujuh bentuk perubahan yakni tiga diantaranya diakibatkan oleh radiasi batu berelemen, dua bentuk lain diakibatkan oleh faktor nurturing happiness berdasarkan pengaruh waktu (siang atau malam), dan dua bentuk terakhir karena pengaruh faktor lokasi tertentu dalam game Pokémon series.

Kehadiran game Pokémon telah menjadi semangat globalisasi dengan menampilkan pertukaran benda-benda/simbol-simbol, pergerakan antar tempat dikombinasikan dengan perkembangan teknologi komunikasi, serta pertemuan dan percampuran kebudayaan dalam era digital. Konsep game Pokémon menekankan pada kemampuan berkomunikasi, location based service untuk menentukan lokasi pemain secara otomatis, accelerometer, dan lain-lain ke dalam genre $R P G$ yang lebih mendekati social game, melalui interaksi (pertemanan maupun konfrontasi pemain dalam game), serta dapat membentuk kelompok berdasarkan lokasi geografis.

Berdasarkan pemaparan di atas, maka penelitian ini akan dibatasi dengan menggunakan metode Manga-matrix untuk pengkajian studi karakter (dalam hal ini pada karakter komik Jepang/manga), dikombinasikan dengan teknik morphological forced connections dan teori warna untuk mengupas studi kasus karakter game Pokémon series untuk mengidentifikasi, menjelaskan dan memberikan pemahaman lebih lanjut tentang transformasi visual desain karakter Eevee dalam game Pokémon series.

\section{$2 \quad$ Metode}

Game Pokémon merupakan game dengan genre RPG yang memiliki kelebihan berupa makna-makna dan simbol budaya pada unsur-unsur karakter, serta gameplay yang dibangun di dalamnya. Makna-makna tersebut muncul berdasarkan pengalaman masa kecil, tradisi, maupun penyederhanaan informasi pengetahuan tentang alam dan fenomena masyarakat Jepang sebagai konsep awal pemikiran desain karakter game Pokémon. Usaha untuk mengangkat dan mengenalkan kebudayaan maupun karakteristik sistem tata nilai masyarakat Jepang terlihat dalam game dan animasi Pokémon seperti: budaya hormat pada orang tua atau yang dituakan, budaya rasa malu dan sikap meminta maaf pada setiap kesalahan, budaya kelompok, budaya sistem hierarki senioritas (nenkoujoretsu), optimisme, kemandirian, kewajiban untuk melakukan setiap tanggung jawab sebaik-baiknya, dan sebagainya yang ditampilkan secara tidak langsung atau yang bersifat semiotik [3].

Creswell [4] memaparkan tentang penelitian dengan pendekatan kualitatif, yang dalam hal ini dilakukan berdasarkan studi kasus yakni penelitian tentang entitas 
tunggal atau fenomena (kasus) dari suatu masa tertentu dan aktivitas (bisa berupa program, kejadian, proses, institusi atau kelompok sosial), melalui pengumpulan detil informasi dengan menggunakan berbagai prosedur pengumpulan data selama kasus itu terjadi.

Penelitian mengenai kajian transformasi visual desain karakter game Pokémon ini untuk menelaah pemaknaan yang terdapat dalam karakter game Pokémon, berdasarkan studi kasus yang dipilih, dengan menguraikan konteks pada ketentuan/konsep yang menjadi tanda visual melalui kajian estetik dari interaktivitas user. Kebudayaan, sistem nilai ataupun karakteristik bangsa Jepang merupakan wujud teks tertulis, sedangkan karakter game Pokémon merupakan teks berupa image.

Penelaahan dua komponen penelitian tersebut berdasarkan pada penelitian kualitatif deskriptif interpretatif dengan pendekatan studi kasus terhadap lingkup kajian estetik yang bertujuan untuk memahami peristiwa bermakna historis dengan penekanan perbedaan individu, sehingga dapat mengembangkan asumsi teori pada konteks dan waktu sebagai bahan penilaian etis/estetis atas terjadinya suatu fenomena (komunikasi) spesifik [5].

\section{Teori yang Digunakan dalam Penelitian}

Sebelum memaparkan teori yang dipergunakan dalam penelitian, perlu disinggung terlebih dahulu tentang topik yang akan disorot dan dikaji lebih lanjut mengenai fenomena-fenomena yang berkaitan dengan kecanduan atau ketertarikan terhadap sesuatu (game), metode manga-matrix, teori warna, teknik morphological forced connections tentang perwujudan visual karakter game yang menjadi bagian dari game Pokémon series.

Berdasarkan data penelitian sejenis tentang Pokémon yang ada sebelumnya, selanjutnya akan dikaji mengenai:

1. Kebudayaan masyarakat Jepang sebagai rumusan dasar/inspirasi pembuatan game Pokémon series.

2. Peranan dan pengaruh rasa penasaran maupun ketertarikan sebagai elemen utama game dengan genre RPG dikaitkan dengan game Pokémon series.

3. Kajian karakter game Pokémon series ditinjau melalui teori manga-matrix, teori warna, serta proses morphological forced connections dalam persepsi aesthetic effect visualisasi desain karakternya.

4. Strategi dan prinsip transformasi desain karakter game Pokémon series.

Sebagaimana yang diungkapkan oleh Schell [6] dalam salah satu bab bukunya, The Power of Pokémon, tentang bagaimana sejarah atau awal mula game Pokémon berkembang menjadi salah satu game dengan kekuatan yang fenomenal melalui transmedia dan fitur-fitur yang ditampilkan melalui komik, 
serial animasi, merchandise, hingga sequel game yang terencana dengan baik dan terbangun secara konsisten serta berkesinambungan. Kekuatan Pokémon tersebut tak hanya pada konsep game semata, namun juga karena peran multimedia sebagai sarana yang menjadikannya sebagai fenomena di dunia game. Ideologi yang diterapkan dalam game Pokémon series adalah pada proses penciptaan desain karakter monster-monster dari Pokémon. Tim kreator game Pokémon membuat desain karakter Pokémon satu per satu, bukan hanya bentuk dan ukurannya saja, tetapi juga sifat-sifat tertentu dari monster-monster tersebut. Menurut Tajiri, setiap karakter Pokémon harus memiliki sifat-sifat yang unik dan mempunyai nama.

Tabel 1 Penggunaan dan Posisi Teori dalam Penelitian.

\begin{tabular}{|c|c|}
\hline Teori & Pokémon \\
\hline $\begin{array}{l}\text { METODE MANGA-MATRIX } \\
\text { - Penciptaan karakter (bentuk, kostum/warna, } \\
\text { sifat). } \\
\text { - Kombinasi elemen-elemen organik dan } \\
\text { anorganik pada karakter. }\end{array}$ & $\begin{array}{l}\text { Curiousity - Addictive factors. } \\
\text { - } \quad \text { Penciptaan dan visualisasi } \\
\text { karakter (bentuk, kostum/ warna, } \\
\text { sifat) dengan matriks elemen } \\
\text { organik dan anorganik. }\end{array}$ \\
\hline $\begin{array}{l}\text { TEORI WARNA } \\
\text { - Pengertian makna simbolis dan makna } \\
\text { psikologis } \\
\text { - Pemahaman sifat-sifat dan efek psikologis } \\
\text { warna. } \\
\text { - Kombinasi penggunaan warna pada karakter } \\
\text { berdasarkan sifat tertentu. }\end{array}$ & $\begin{array}{l}\text { Penerapan kombinasi warna- } \\
\text { warna sebagai pendekatan sifat } \\
\text { psikologis karakter Pokémon. } \\
\text { Perwujudan prinsip-prinsip estetik } \\
\text { dalam karakter game. }\end{array}$ \\
\hline $\begin{array}{l}\text { TEKNIK MORPHOLOGICAL FORCED } \\
\text { CONNECTIONS } \\
\text { - Penghubung parameter objek kajian. } \\
\text { - Kombinasi elemen dan eksplorasi kemungkinan } \\
\text { pemecahan masalah. }\end{array}$ & $\begin{array}{l}\text { Analisis korelasi antar teori referensi } \\
\text { dalam proses transformasi visual } \\
\text { desain karakter game Pokémon series. }\end{array}$ \\
\hline
\end{tabular}

Ada tiga teori yang dipaparkan sehubungan dengan pengkajian transformasi visual desain karakter dari game Pokémon bagi penelitian ini, yakni:

1. Metode Manga-matrix yang dikemukakan oleh Tsukamoto [7] yang digunakan untuk mengkaji karakter game dengan referensi yang tidak terbatas (unlimited). Matriks karakter yang dimaksud antara lain: form matrix, costume matrix, dan personality matrix.

2. Teori warna berdasarkan pemaparan Brewster dalam Sulasmi Darmaprawira W.A. [8], hasil pengembangan teori Newton dan Munsell yang digunakan untuk mengkaji faktor penggunaan warna serta pemahaman tentang makna warna secara simbolis dan psikologis terhadap karakter game.

3. Teknik Morphological Forced Connections sesuai pemaparan Koberg dan Bagnall [9] sebagai metode penyatuan otomatis parameter-parameter ke dalam suatu kombinasi baru sebagai tahapan pemecahan masalah. 
Teori-teori yang dipergunakan dalam penelitian ini satu sama lain saling terikat dan melengkapi, yang menjadi dasar pijakan penelitian mengenai pembahasan transformasi visual desain karakter Pokémon dalam game Pokémon series. Pada Tabel 1 dipaparkan tentang penggunaan teori dan posisinya dalam penelitian.

\section{Game Pokémon Series sebagai Role Playing Game}

Pokémon pertama kali diciptakan oleh Satoshi Tajiri, seorang desainer game yang juga penggemar serangga, sekitar akhir tahun 1990-an oleh Game Freak dalam format RPG untuk GameBoy, handheld video game buatan Nintendo. Game Pokémon yang pertama dirilis yaitu Pokémon Red dan Pokémon Green pada tahun 1995 di Jepang. Selanjutnya pada tahun 1998, dirilis Pokémon Red dan Pokémon Blue untuk pasar game di luar Jepang. Setelah sukses dengan versi game, Pokémon kemudian dibuat versi anime, manga, movie, trading card, hingga berbagai franchise lainnya.

Sampai saat ini terdapat 649 karakter Pokémon, mulai dari generasi pertama hingga generasi kelima, yang terdiri dari beberapa jenis/tipe dengan kelemahan dan keunggulan tersendiri terhadap tipe-tipe tertentu. Seperti Pokémon air yang unggul melawan Pokémon tipe tanah, namun lemah terhadap Pokémon tipe listrik.

Proses penangkapan Pokémon menggunakan alat bernama Pokéball (bola yang dipakai untuk menangkap Pokémon), Pokédex (ensiklopedi Pokémon yang berisi data-data setiap Pokémon), dan berbagai perlengkapan lainnya. Dunia Pokémon terjadi di beberapa region seperti: Kanto, Johto, Hoenn, Sinnoh, dan Unova dengan karakteristik Pokémon, Gym, dan turnamen Pokémon tersendiri.

Game Pokémon series, terlepas dari versi-versi game yang ada itu sendiri, tergolong ke dalam genre RPG karena memiliki unsur storyline dan karakter yang sangat beragam di dalamnya. Ciri-ciri RPG yang mudah dijumpai dalam permainannya sendiri adalah apabila memasuki sesi battle atau pertarungan akan berpindah/berganti ke frame lain ${ }^{1}$. Sedangkan secara detil ciri-ciri dari RPG dapat diuraikan sebagai berikut ini:

1. Terdapat karakter musuh atau monster sepanjang permainan

2. Terdapat unsur leveling, inventory, skill

3. Terdapat unsur quest atau misi terhadap suatu kepentingan yang harus diselesaikan

4. Terdapat unsur item, magic, equip, dan shop untuk upgrading level karakter yang dimainkan

5. Memiliki gauge system seperti: HP, MP, SP, dan lain sebagainya.

\footnotetext{
${ }^{1}$ Disarikan berdasarkan artikel "Game Center - The Gamer’s Site: Genre in Games!!" yang diunggah pada 25
} Januari 2010 dari blog http://gamerscenter.blogspot.com/2010/01/. 
Pola permainan game Pokémon series tidak memiliki banyak perubahan dalam hal alur cerita (storyline), melainkan terdapat beberapa fitur baru pada setiap seri permainannya. Menurut Crawford [10], salah satu cara untuk menggambarkan alur interaksi dalam game adalah melalui alur cerita game itu sendiri. Dalam game Pokémon series, alur interaksi bergerak searah/lurus dengan alur cerita yakni berawal dari start sampai finish. Alur interaksi yang ada dimulai dengan memilih karakter avatar serta Pokémon starter untuk dimainkan (berpetualang, bertarung dengan Pokémon liar maupun Pokémon milik trainer lain, dan lain sebagainya).

Evolution atau shinka dalam bahasa Jepang (進化) adalah perubahan wujud fisik yang terjadi pada Pokémon, mengarah kepada proses perkembangan tahapan metamorfosis daripada konteks evolusi yang sebenarnya, akibat adanya peningkatan stats values pada Pokémon. Evolusi yang terjadi pada Pokémon terjadi karena beberapa alasan, salah satunya akibat unsur penambahan battle experience yang menjadikan Pokémon lebih kuat daripada sebelumnya.

Evolusi Pokémon dapat dibagi menjadi beberapa tahapan berdasarkan pada asal atau tipe Pokémon itu sendiri. Semua Pokémon dibagi ke dalam empat kelompok yakni (Gambar 1): baby Pokémon (wujud awal Pokémon), unevolved Pokémon (Pokémon yang tidak berevolusi), first-evolution Pokémon (wujud evolusi pertama Pokémon), dan second-evolution Pokémon (wujud evolusi kedua Pokémon).

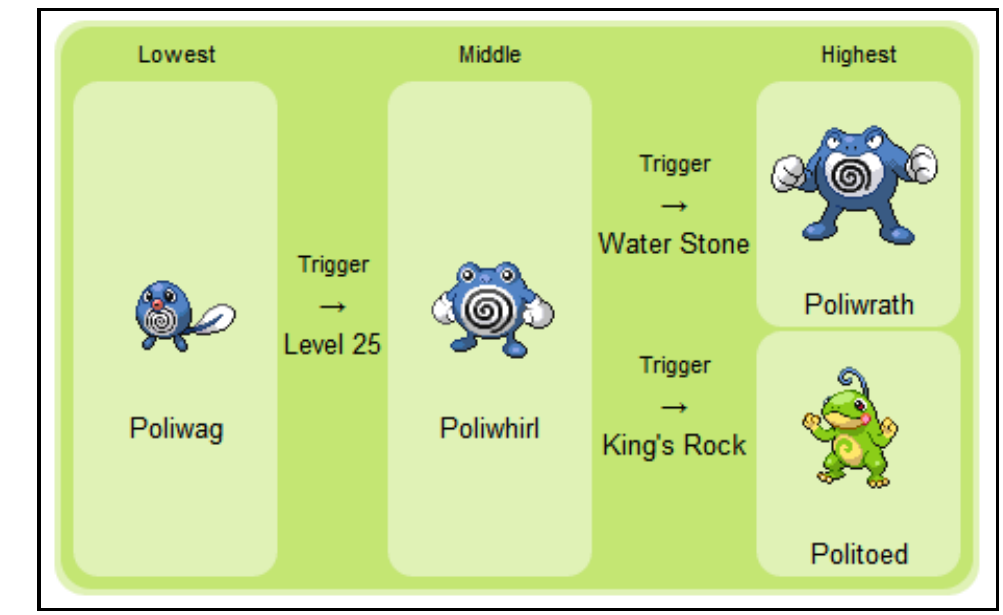

Gambar 1 Tingkatan transformasi Pokémon dua tahapan perubahan bercabang. Sumber: www.pokemonzone.com. 


\section{Eevee sebagai Karakter Pokémon dalam Penelitian}

Berdasarkan teori utama yang digunakan dalam penelitian ini, yakni mangamatrix yang pada dasarnya memiliki keterikatan dan saling melengkapi dengan teori game lain, objek kajian penelitian akan difokuskan mengenai pembahasan karakter dalam game Pokémon series. Teori game (theory of game) sebagai referensi umum dari penelitian ini dan teori manga-matrix dipergunakan sebagai gambaran/referensi mengenai studi pengenalan terhadap penciptaan karakter, sebagai elemen dalam game yang dimainkan oleh para responden. Karakter Eevee dipilih sebagai objek studi kasus penelitian sebagai karakter Pokémon yang dianggap cukup familiar bagi responden karena memiliki variasi evolusi terbanyak (Gambar 2).

Secara umum, fisiologi dari karakter Eevee menurut pemaparan Sugimori tergolong dalam kelas Mammalia yang bercirikan sebagai berikut:

1. Memiliki bulu yang lebat di seluruh tubuhnya.

2. Merupakan hewan pemakan daging yang hidup terestrial, kakinya berjari lima, kadang-kadang empat dan bercakar, bertaring kuat dan tajam, serta memiliki geraham yang runcing.

3. Tergolong dalam kelompok Eutheria yakni mamalia berplasenta dan termasuk ke dalam ordo Carnivora dengan pembagian tiga golongan besar yakni famili Canidae, ekor pendek dan berambut, mulut runcing, kaki bulat dan panjang (contoh: anjing); famili Mustelida, kaki berjari lima dan bercakar yang tidak dapat ditarik, berkelenjar kesturi (contoh: anjing air); serta famili Felidae, bentuk gigi untuk mengunyah dan mengoyak, kepala agak bulat dan moncongnya pendek, terdapat bercak-bercak yang kasar (contoh: kucing peliharaan dan harimau).

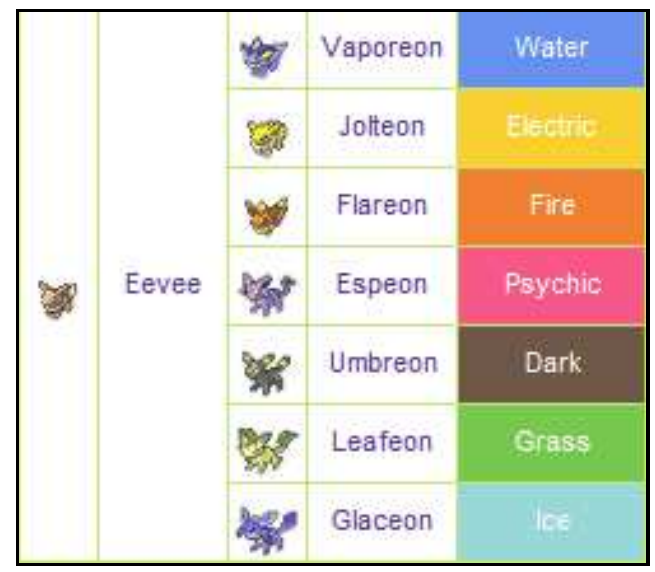

Gambar 2 Eevee dan beberapa perubahan wujud transformasinya. Sumber: www.pokemonzone.com. 
Eevee ditampilkan sebagai karakter Pokémon hasil imajinasi dan kombinasi berbagai referensi citra hewan yang ada, dalam hal ini adalah anjing dan kucing, dengan ciri-ciri: seluruh tubuh tertutup bulu berwarna coklat, ekor lebat seperti semak dengan warna lebih muda, gading, di ujung ekornya serta pada bulu lebat di sekeliling lehernya, memiliki empat kaki pendek menyerupai kaki kucing dengan tiga jari kaki kecil di setiap kakinya, telinga panjang berujung lancip, dan bantalan cakar berwarna merah muda. Dengan demikian, Eevee memiliki berbagai ciri-ciri umum yang ada pada hewan-hewan seperti kelinci, rubah, anjing, dan kucing.

Klasifikasi dan analisis karakter Eevee untuk selanjutnya akan menerapkan prinsip keilmuan Biologi dengan pengelompokan makhluk hidup seperti Gambar 3 berikut ini:

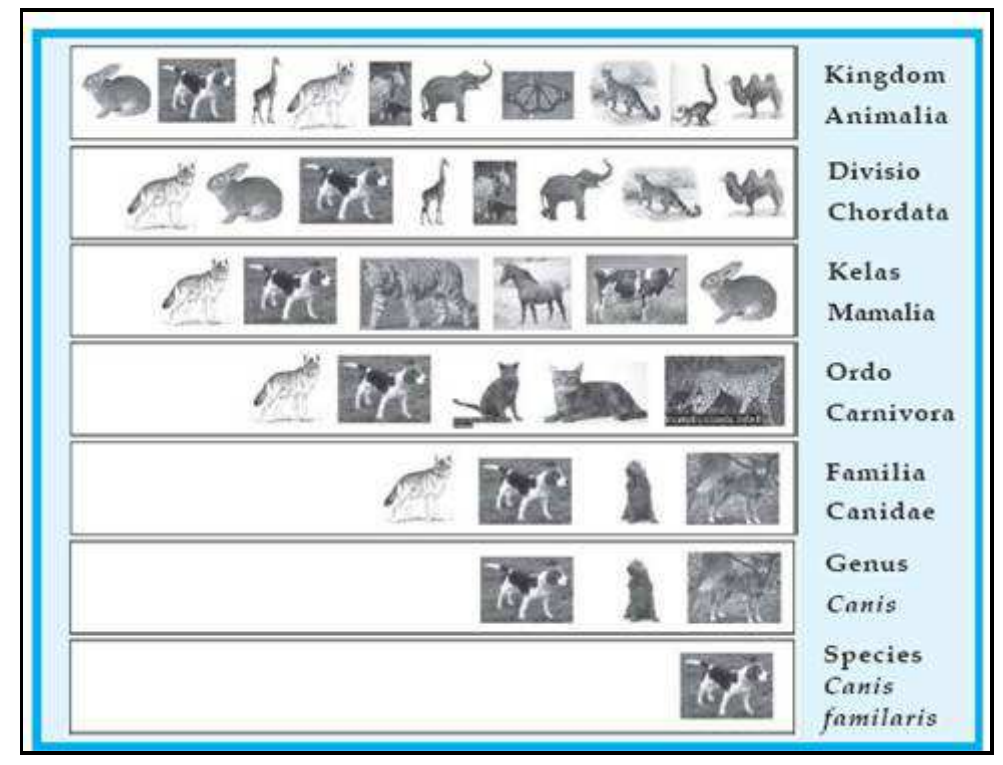

Gambar 3 Pembagian makhluk hidup (hewan) menurut keilmuan Biologi. Sumber: http://biologigonz.blogspot.com/2010/06/mamalia.html.

\section{Pengkajian Transformasi Visual Desain Karakter Eevee Pada Game Pokémon Series Generasi I-V}

Morphological Forced Connections merupakan teknik awal yang digunakan untuk menghubungkan beberapa parameter/elemen visual yang terdapat pada karakter Eevee, objek kajian dalam penelitian ini, seperti yang ditunjukkan pada Tabel 2 berikut: 
Tabel 2 Matriks karakter Eevee.

\begin{tabular}{|c|c|c|c|c|c|c|c|}
\hline \multicolumn{8}{|c|}{ Eevee } \\
\hline Mata & Telinga & Hidung & Mulut & Leher & Badan & Kaki & Ekor \\
\hline
\end{tabular}

Tabel 3 Matriks struktur anatomi Eevee.

Telinga


Tabel 2 memperlihatkan pembagian unsur-unsur visual karakter Eevee yang menjadi parameter dalam analisis yang akan dipaparkan secara lebih detil terkait dengan transformasi visual karakter Eevee dan turunannya pada sub-bab berikutnya. Pembagian elemen-elemen visual karakter Eevee tersebut dilakukan berdasarkan fisiologi dasar tampilan yang menjadi pengenal/identitas pengenal suatu makhluk hidup antara lain: bagian muka (mata, hidung, mulut, telinga) dan bagian badan (leher, kaki, ekor, warna kulit/tubuh).

Tahapan selanjutnya adalah pemaparan mengenai pemecahan elemen karakter Eevee berdasarkan struktur anatominya. Pemecahan struktur anatomi Eevee berdasarkan pada tiga jenis hewan yakni: anjing (Canine), kucing (Feline), dan kelinci (Lepus) karena ketiga golongan hewan tersebut merupakan hewan yang disukai anak-anak.

Pemecahan elemen-elemen desain karakter Eevee dikaitkan dengan struktur anatomi pada Tabel 3 di atas, tampak terlihat beberapa kombinasi antara hewan dari genus Feline, Canine, maupun Lepus. Pada baris pertama dan ke-2 yakni mata dan telinga Eevee dapat dikategorikan ke dalam mata golongan hewan Canine dan Lepus. Baris ke-3 dan ke-7 menampilkan hidung dan kaki Eevee yang memiliki ciri hewan Feline. Baris ke-4 dan ke-8 menampilkan mulut dan ekor Eevee yang memiliki persamaan ciri hewan Lepus. Sedangkan baris ke-5 dan ke-6 menampilkan bagian leher dan badan Eevee dengan ciri-ciri yang serupa dengan hewan Feline sekaligus Lepus. Walaupun secara keseluruhan kesan yang ada pada Eevee adalah semacam hewan peliharaan yang friendly, sebagaimana halnya kesan hewan Canine, namun pada kenyataannya tidaklah demikian. Eevee merupakan salah satu karakter Pokémon yang memiliki unsur maupun sifat dari hasil kombinasi ketiga rujukan hewan yang dimaksud.

Pada Tabel 4 matriks MFC karakter Eevee di atas, elemen-elemen penelusuran awal yang terdapat pada Tabel 3 mulai terlihat alur penciptaannya oleh Ken Sugimori, kreator karakter Eevee. Karakter Eevee yang diciptakan oleh Sugimori memiliki konsep awal sebagai mamalia dengan bulu lebat berwarna coklat, berekor tebal dengan warna gading di bagian ujungnya, serta bulu leher dengan warna yang senada. Eevee digambarkan memiliki mata berwarna coklat, telinga panjang dan besar, serta bantalan cakar kaki berwarna merah muda. Secara umum, tampilan karakter Eevee menampilkan karakteristik yang ada pada hewan rubah Fennec, yakni rubah berukuran kecil yang dapat hidup di daerah gurun. Karakter Eevee dan turunan wujud perubahannya (dalam game Pokémon series disebut dengan istilah evolusi) memiliki karakteristik hewan rakun, rubah, anjing, dan kucing. 
Tabel 4 Matriks MFC karakter Eevee.

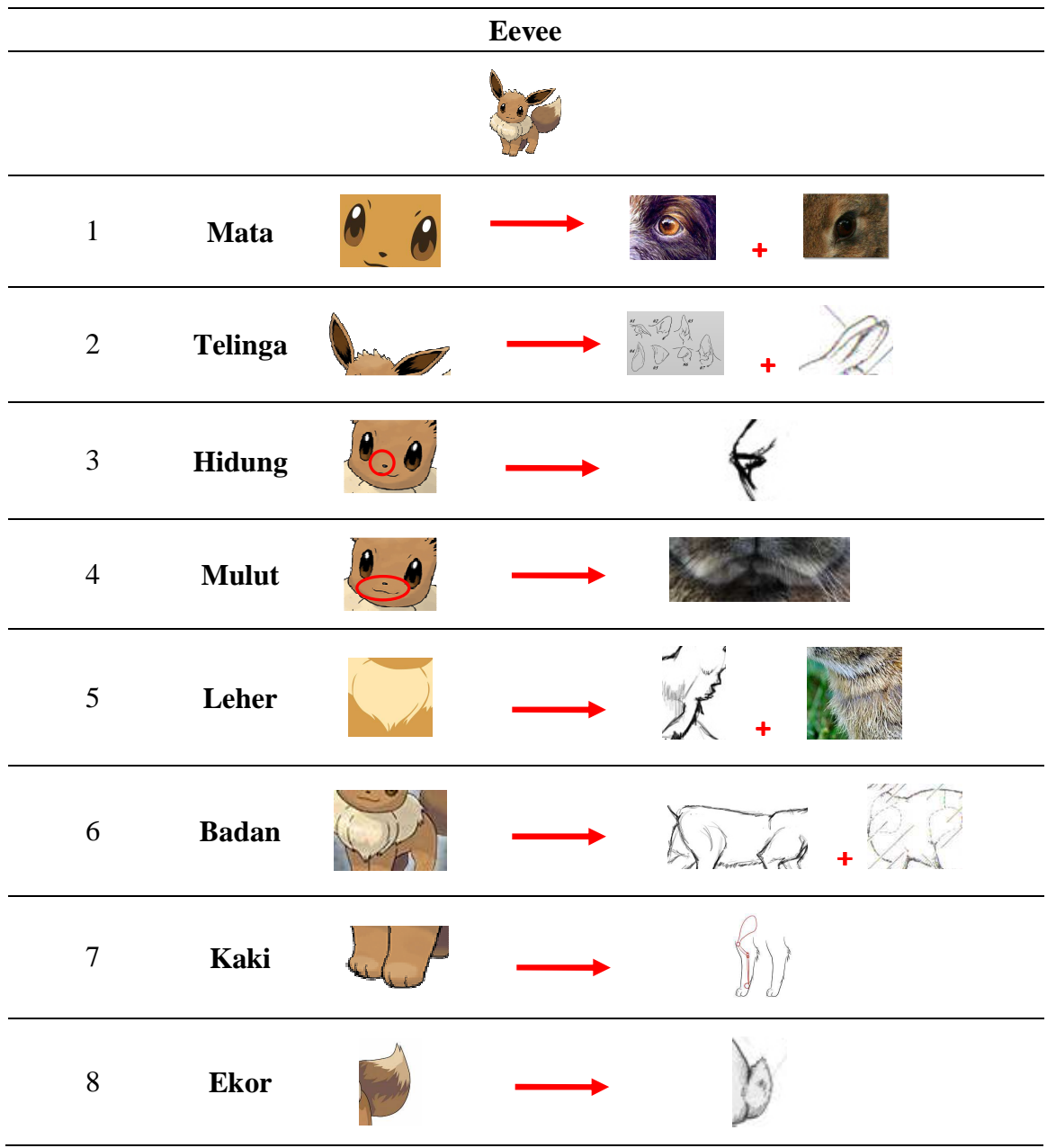

Perbandingan transformasi visual karakter Eevee dan evolusinya dengan penerapan gagasan pencitraan dari penciptaan karakter yang ada melalui teori Manga-matrix yakni penerapan suatu kombinasi gagasan terhadap bentuk, wujud, maupun komposisi di dalamnya. Elemen-elemen tersebut kemudian diolah sedemikian rupa, sehingga rumusan dasar dari gagasan penciptaan karakter yang cukup familiar dan memudahkan bagi pengamat untuk dapat mengenali perubahan yang terjadi, baik wujud awal maupun wujud akhirnya dapat diketahui dan mudah dikenali oleh pengamat (lihat Tabel 5-7). 
Transformasi Visual Desain Karakter pada Game Pokémon 167

Tabel 5 Tabel perubahan karakter Eevee akibat batu evolusi, pengaruh waktu, dan faktor lokasi.

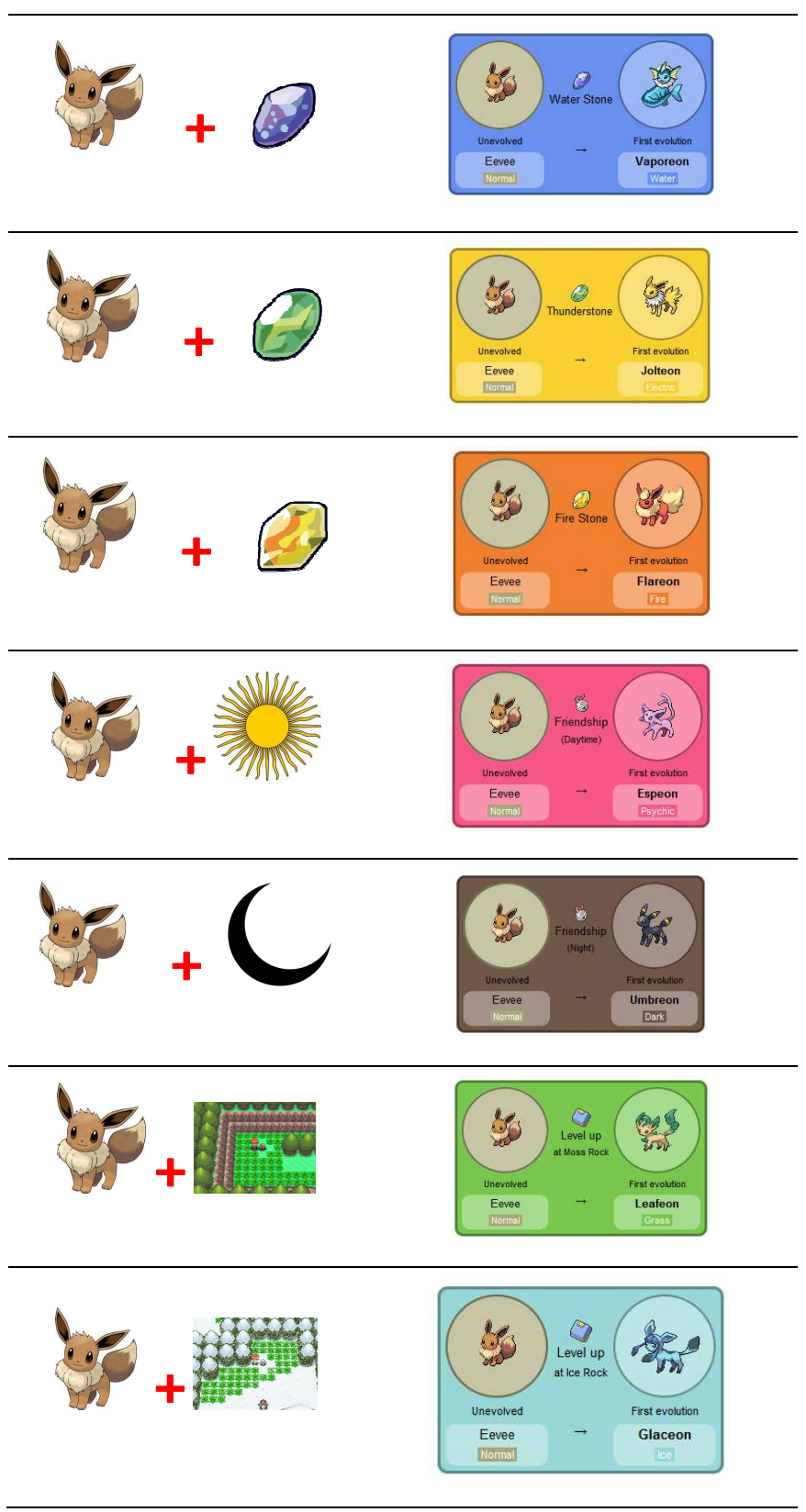


Tabel 6 Tabel perbandingan transformasi visual karakter Eevee.

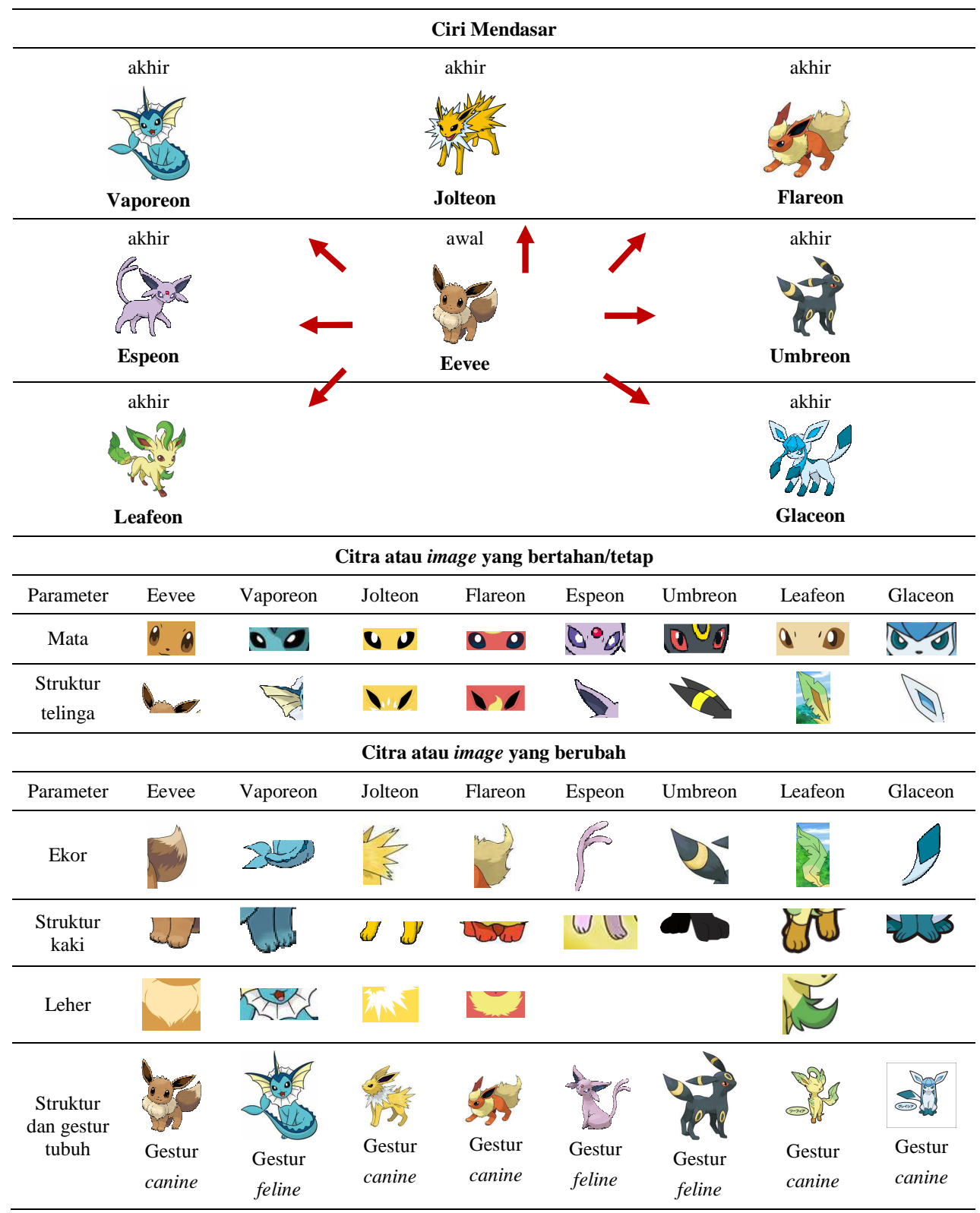


Transformasi Visual Desain Karakter pada Game Pokémon 169

Tabel 7 Tabel analisis transformasi visual desain karakter Eevee.

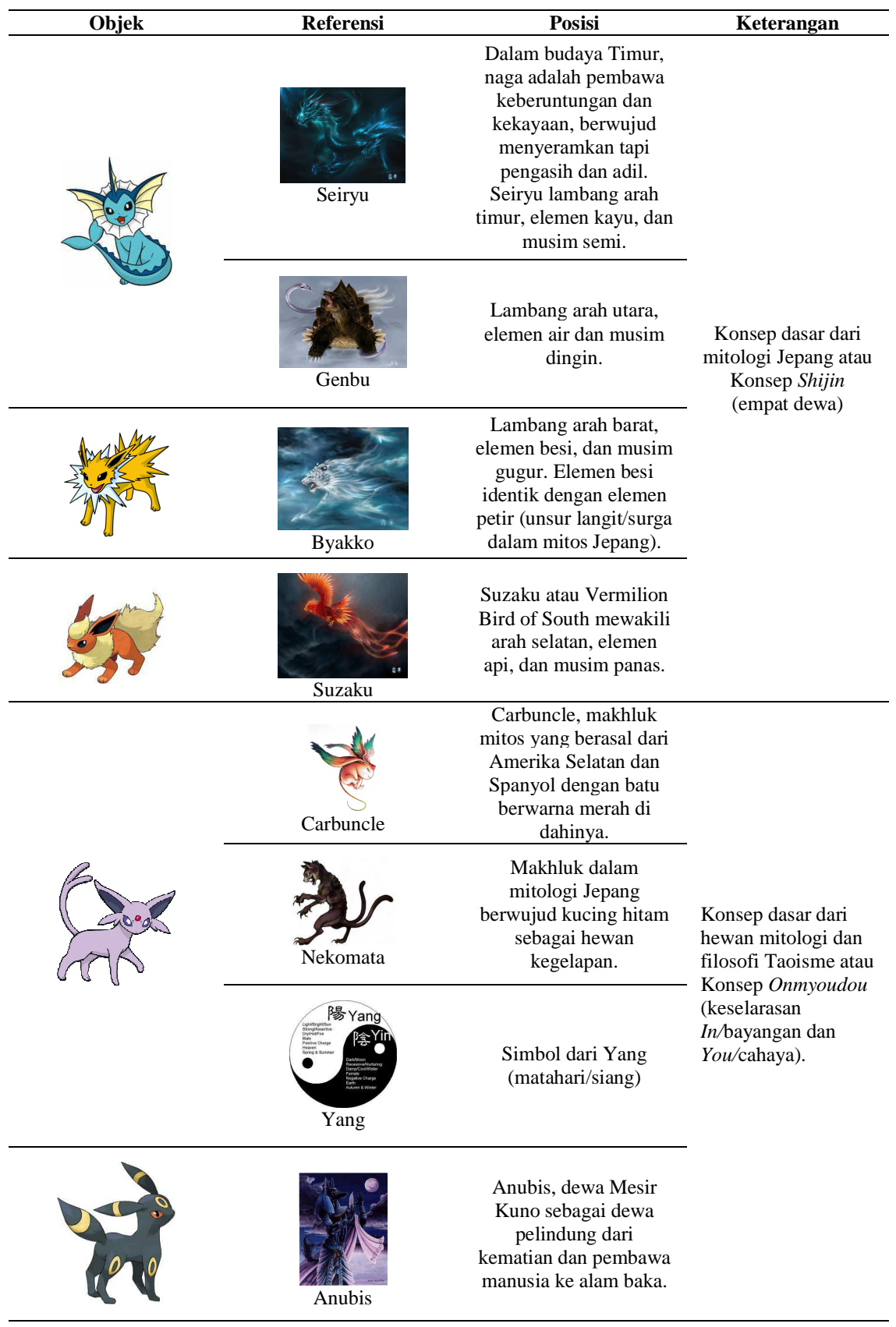


Tabel 7 (Lanjutan) Tabel analisis transformasi visual desain karakter Eevee.

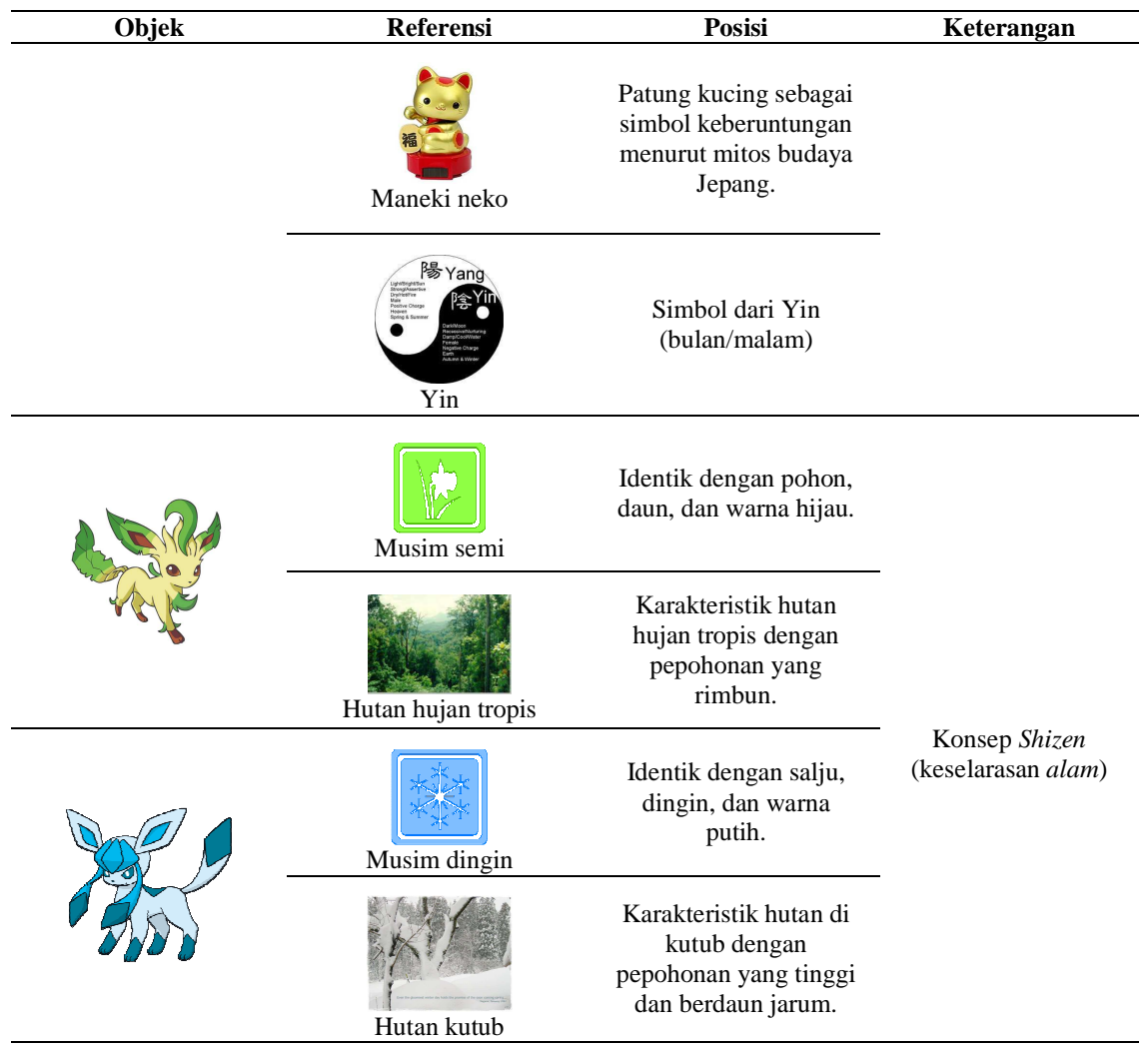

Dengan demikian, hasil analisis karakter Eevee dan turunan perubahan wujud atau bentuk transformasi (evolusi) yang ada pada generasi game Pokémon series dapat diuraikan sebagai berikut:

1. Terdapat perubahan (transformasi) terhadap elemen-elemen yang berkaitan dengan tampilan grafis karakter secara menyeluruh seperti image hewan karakter, dimensi tubuh, dan warna.

2. Perubahan warna yang terjadi pada karakter Eevee, Vaporeon, Jolteon, Flareon, Espeon, Umbreon, Leafeon dan Glaceon terkait pada warna tubuh dan beberapa bagian tubuh, secara tidak langsung mengindikasikan keanekaragaman elemen kekuatan antara satu dengan yang lain.

3. Elemen-elemen perubahan terdapat pada bagian tubuh yang mewakili image representatif dari hewan yang ada di dunia nyata meliputi daun telinga, kepala, tubuh maupun ekor sesuai dengan karakteristik elemen yang dimilikinya. 
4. Elemen-elemen dan warna yang terdapat pada Eevee dan turunannya merupakan gambaran singkat dari elemen-elemen kehidupan yakni: bumi, air, listrik, api, cahaya, kegelapan, pohon (musim semi/musim panen), dan es (musim dingin).

5. Perubahan wujud yang terjadi pada karakter Eevee, Vaporeon, Jolteon, Flareon, Espeon, Umbreon, Leafeon dan Glaceon memiliki keanekaragaman elemen, sehingga transformasi baru banyak menampilkan bentuk yang variatif karena memiliki pola persamaan pada image hewan aslinya yakni ordo Carnivora (Feline dan Canine) dengan variasi yang beragam.

6. Karakter Eevee sebagai salah satu karakter Pokémon evolusi dalam game Pokémon series memiliki kemungkinan terbanyak untuk olahan bentuk dan fleksibilitas tinggi untuk pengembangan karakter berikutnya dengan sifat maupun elemen-elemen yang cukup beragam.

7. Karakter Eevee terinspirasi dari hewan ordo carnivora seperti kucing, anjing, dan rubah yang memiliki beragam ras/jenis.

8. Hewan kucing dengan berbagai macam rasnya merupakan salah satu dari sekian banyak jenis hewan yang dipuja di Jepang. Adanya faktor tradisi dari mitologi Jepang tentang peranan hewan kucing dalam legenda dua belas shio hingga sebagai hewan kesayangan Dewa Matahari, membuat kucing menjadi karakter yang patut diperhitungkan pengaruhnya dalam setiap penciptaan karakter turunan Eevee dalam game Pokémon series.

9. Hewan anjing juga menjadi salah satu inspirasi karakter Eevee yang banyak diceritakan tentang kesetiaan seekor anjing kepada pemiliknya, seperti Hachiko dan kisah-kisah kepahlawanan dalam mitologi maupun legenda rakyat Jepang yang lainnya.

10. Karakter Eevee yang berjenis Pokémon evolusi dalam game Pokémon series memberikan pengaruh yang sangat signifikan terhadap kemungkinan penciptaan karakter baru berdasarkan imajinasi para fans Pokémon atau fanfiction seperti beberapa Gambar 4 dan 5 berikut ini:

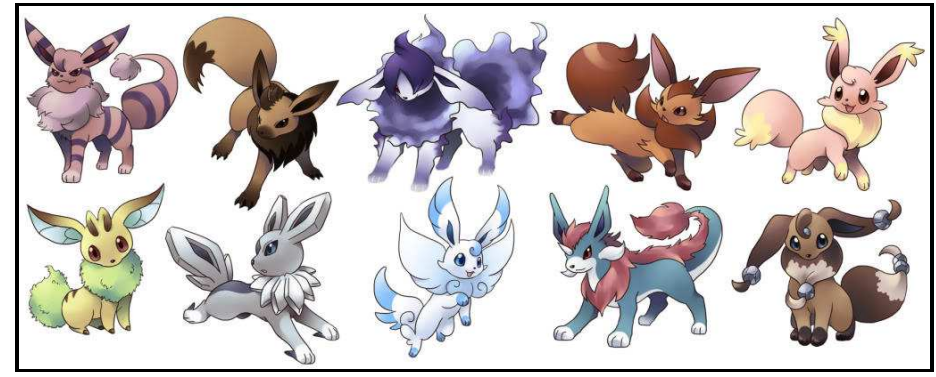

Gambar 4 Beberapa karakter fanfiction dari Eevee (Bag.1). Sumber: http://www.pokecommunity.com. 


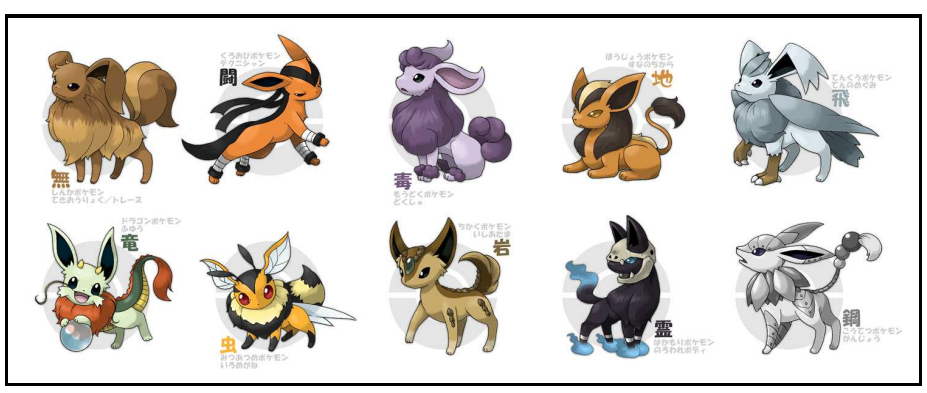

Gambar 5 Beberapa karakter fanfiction dari Eevee (Bag. 2). Sumber: http://151chan.org/smeargle/src/13016886718.jpg.

Pada analisis transformasi karakter Eevee dan wujud evolusinya maupun antara karakter Eevee dengan karakter fanfic hasil turunannya, dapat ditemukan berbagai macam percampuran dan persilangan karakteristik organik hewan yang cukup beragam, dalam hal ini adalah fisiologis dari Canine dan Feline, sebagai wujud dari penerapan teori Manga-matrix sebagai acuan dalam penciptaan visualisasi karakter. Referensi mitologi-mitologi dunia (Yunani, Mesir, Inca, dan sebagainya) memberikan peranan yang cukup signifikan terhadap visualisasi karakter manga atau game pada umumnya, dan karakter Eevee pada khususnya. Namun, ciri khas pada semua karakter dalam komik dan game Jepang memiliki persamaan yang cukup signifikan yakni mengangkat tentang tema budaya bangsa Jepang, baik dari segi filosofi, kepercayaan, cara hidup, dan lain-lain. Dengan demikian, paparan mengenai transformasi visual desain karakter Eevee dalam game Pokémon series dapat dirangkum ke dalam Tabel 8 seperti berikut ini:

Tabel 8 Tabel rangkuman konsep visualisasi karakter Eevee.

\begin{tabular}{cclc}
\hline Objek & & \multicolumn{1}{c}{ Referensi } & Konsep dasar \\
\hline Vaporeon & - & Konsep Shijin (empat dewa) & \\
Jolteon & - & Konsep elemen alam & \\
Flareon & - & Konsep warna primer & \\
Espeon & - & Konsep mitologi hewan & Filosofi bangsa \\
Umbreon & - & Filosofi Taoisme & Jopang \\
& & $\begin{array}{l}\text { Konsep Onmyoudou } \\
\text { (keselarasan In/bayangan } \\
\text { dan You/cahaya) }\end{array}$ & \\
\hline Leafeon & & $\begin{array}{c}\text { Konsep Shizen } \\
\text { (keselarasan alam) }\end{array}$ & \\
\hline Glaceon & &
\end{tabular}

\section{Kesimpulan}

Salah satu ciri yang mendasar dari Pokémon adalah terdapat unsur transformasi di dalamnya, yakni perubahan wujud suatu Pokémon dari wujud awal menjadi 
wujud yang lebih kuat. Konsep transformasi yang ada dalam game Pokémon series sebagai wujud penggabungan fiksi dengan teori ilmiah. Adanya transformasi karakter dalam dunia Pokémon terjadi akibat faktor experience, kenaikan level disertai kenaikan kemampuan (ability) Pokémon yang bersangkutan. Namun, satu hal penting dalam dunia Pokémon adalah bahwa tidak semua Pokémon mengalami proses transformasi. Sebagian Pokémon tetap dalam wujud awalnya walaupun telah dikenai atau mengalami berbagai macam perlakuan terhadapnya.

Melalui analisis data yang telah dilakukan, teridentifikasi bahwa wujud transformasi Pokémon memiliki suatu benang merah persamaan dengan wujud awalnya. Adanya elemen-elemen tambahan pada wujud transformasi Pokémon tertentu telah memberikan keragaman bentuk pada visualisasi karakter Pokémon. Ragam bentuk Pokémon tersebut menjadi dasar penciptaan karakter sebagai media pengenalan transformasi visual desain karakter suatu game, dalam hal ini adalah game Pokémon series.

Hasil analisis mengenai transformasi visual desain karakter game Pokémon series didapat sebagai berikut:

1. Warna-warna pada desain karakter game Pokémon series merupakan warna sekaligus objek pembentuk lingkungan (environment) yang diminati pemain karena banyak menggunakan pilihan warna-warna cerah dan colourful.

2. Tema yang ditampilkan dalam game Pokémon series selalu menampilkan unsur keseimbangan alam, interaksi antar makhluk hidup, persahabatan, dan perdamaian sesuai dengan filosofi dalam kebudayaan Timur seperti: filosofi Taoisme (Cina) maupun paham naturalisme Buddha atau Shizenshugi (Jepang), sangat disukai dan sesuai untuk semua kalangan umur.

3. Visualisasi desain karakter Pokémon sebagian besar dibuat berdasarkan karakteristik hewan yang ada di sekitar manusia. Dalam dunia desain/arsitektur hal ini disebut pengembangan desain Organic-Animal Analogy, sebagai salah satu metode penciptaan karakter Pokémon dari hasil penganalogian hewan asli.

4. Terdapat perubahan visual desain karakter Pokémon ke arah yang lebih sederhana dari kenyataan kompleksitas sebenarnya, menjadi lebih subjektif dibandingkan objektif, lebih ikonik daripada realistik, serta lebih universal dan tidak spesifik.

Secara keseluruhan tampilan visual desain karakter-karakter Pokémon yang ada merupakan hasil dari terapan metode Manga-matrix yang berperan dalam setiap proses transformasi visual desain untuk menciptakan karakter Pokémon yang tidak terbatas.

Penelitian tentang transformasi visual desain karakter Eevee dalam game Pokémon series ini merupakan tahap awal pengenalan metode Manga-matrix, 
teknik morphological forced connections, serta teori warna sebagai metode untuk menciptakan karakter-karakter yang tidak terbatas. Selain itu, terdapat beberapa rekomendasi mengenai perbaikan dan tambahan konten yang mungkin perlu dilakukan untuk penelitian berikutnya, antara lain:

1. Kaitan gameplay dengan karakter yang dimainkan sehingga pemain akan lebih memahami mengenai interface yang ditampilkan dari karakter Pokémon tertentu dan dapat memiliki wawasan melalui pengamatan lebih lanjut.

2. Pengaruh adanya faktor gender pemain dari game Pokémon series terhadap pemilihan karakter Pokémon yang dimainkan yang menjadi salah satu pertimbangan munculnya transformasi visual desain karakter Pokémon, baik dari segi konteks masyarakat Jepang (creator) maupun konteks pemain (user).

3. Komparasi game sejenis yang dapat menjadi bahan kajian mengenai studi karakter atau konsep penciptaan suatu karakter berdasarkan elemen-elemen visual suatu game. Misalnya komparasi antara game Pokémon dengan game Digimon atau game Pokémon dengan game Monster Rancher, dan lain sebagainya.

4. Perlu diperkaya inventarisasi parameter-parameter yang digunakan dalam teori Manga-matrix untuk memperoleh data-data yang faktual dan akurat guna mengkaji dan memperkaya metode transformasi visual desain karakter game.

\section{Referensi}

[1] Smardon, R. 1986. Foundations of Visual Project Analysis, New York: John Wiley and Sons, Inc.

[2] Fox, B. 2005. Game Interface Design, Boston: Thomson Course Technology PTR.

[3] Suryohadiprojo, S. 1982. Manusia dan Masyarakat Jepang dalam Perjoangan Hidup, Jakarta: UI Press dan Pustaka Bradjaguna.

[4] Creswell, J.W. 2007. Qualitative Inquiry and Research Design Choosing Among Five Approaches, USA: Sage Publication.

[5] Mulyana, D. 2001. Metodologi Penelitian Kualitatif - Paradigma Baru Ilmu Komunikasi dan ilmu Sosial Lainnya, Bandung: PT. Remaja Rosdakarya.

[6] Schell, J. 2008. The Art of Game Design-A Book of Lenses. Burlington: Morgan Kaufmann Publishers.

[7] Tsukamoto, H. 2006. Manga Matrix: Create Unique Characters Using the Japanese Matrix System, USA: Collins Design.

[8] Darmaprawira, S. 2002. Warna-Teori dan Kreativitas Penggunaannya, Edisi ke-2, Bandung: Penerbit ITB. 
Transformasi Visual Desain Karakter pada Game Pokémon 175

[9] Koberg, D. \& Bagnall, J. 1981. The All New Universal Traveler, California: William Kaufmann.

[10] Crawford, C. 2003. Chris Crawford on Game Design, USA: New Riders Publishing. 